\title{
Дестабилизация вин. Кристаллообразование калиевых солей
}

\author{
Нонна Владимировна Гниломедова, канд. техн. наук, доцент, вед. науч. сотр. лаборатории химии и биохимии вина, \\ 231462@mail.ru; https://orcid.org/0000-0003-1784-2370; \\ Надежда Станиславовна Аникина, д-р техн. наук, ст. науч. сотр., зав. лабораторией химии и биохимии вина, \\ hv26@mail.ru; https://orcid.org/0000-0001-5682-3426; \\ София Николаевна Червяк, канд. техн. наук, науч. сотр. лаборатории химии и биохимии вина, Sofi4@list.ru; \\ https://orcid.org/0000-0001-9551-7448 \\ Федеральное государственное бюджетное учреждение науки «Всероссийский национальный научно-исследовательский институт \\ виноградарства и виноделия «Магарач» РАН», Россия, Республика Крым, 298600, г. Ялта, ул. Кирова, 31
}

Среди различных причин потери товарного вида вин наиболее частой является кристаллическая дестабилизация за счет выпадения виннокислых солей. В большинстве случаев осадок представлен калиевой, реже - кальциевой солью. Изменение климатических условий, наблюдаемое за последнее время, расширение сырьевой базы, внедрение новых приемов воз делывания винограда и технологии его переработки, а также использование современных вспомогательных материалов для виноделия влияет на коллоидный и минеральный состав вин, в результате чего общепринятые способы кристаллической стабилизации, а также методы диагностики вин на склонность к кристаллообразованию являются недостаточно эффективными. В данном литературном обзоре изложены современные представления о механизмах формирования в винах микро- и макрокристаллов битартрата калия. Показано, что кристаллическая дестабилизация вин зависит от множества разнонаправленно влияющих факторов, таких как температура вина, объемная доля этилового спирта, содержание коллоидных веществ, а также катионно-анионного состава, обусловливающего значение $\mathrm{pH}$, ионную силу раствора и степень диссоциации органических кислот. Приведены количественные выражения и взаимосвязи содержания катионов калия и анионов винной кислоты, дестабилизирующих систему вина, с агротехническими особенностями возделывания винограда и технологическими приемами его переработки. Обоснована необходимость разработки новых методологических подходов для контроля и регулирования кристаллической стабильности вин на основе изучения качественного состава сырья и продуктов его переработки на всех этапах производства.

Ключевые слова: калий; винная кислота; битартрат калия; катионно-анионный состав; коллоидные вещества; агротехнические приемы; способы переработки винограда; ингибиторы и провокаторы кристаллообразования.

$A$ мя реализации «Стратегии повышения качества пищевой продукции в Российской Федерации ао 2030 года» (утв. распоряжением Правительства РФ от 29 июня 2016 г. № 1364-р) необходимым условием явмяется внеАрение фундаментальных исследований в направлении совершенствования и развития методологической базы с целью мониторинга качества и безопасности пищевой продукции.

Как цитировать эту статью:

Гниломедова Н.В., Аникина Н.С., Червяк С.Н. Дестабилизация вин. Кристаллообразование калиевых солей // «Магарач» Виноградарство и виноделие. 2019; 21(3). С. 261-266. DO 10.35547/IM.2019.21.3.014

How to cite this article:

Gnilomedova N.V., Anikina N.S., Chervyak S.N. Wine destabilization. Potassium salts crystall formation. Magarach. Vinogradarstvo $i$ vinodelie=Magarach. Viticulture and Winemaking 2019; 21(3):261-266. DOI 10.35547/IM.2019.21.3.014 (in Russian)

удК 663.252.35/.258.2:54-128.2/.4

Поступила 17.05.2019

Принята к публикации 20.08.2019

(с)Авторы, 2019

\section{R E V I E W \\ Wine destabilization. Potassium salts crystall formation}

Nonna Vladimirovna Gnilomedova, Nadezhda Stanislavovna Anikina, Sofia Nikolaievna Chervyak

Federal State Budget Scientific Institution All-Russian National Research Institute of Viticulture and Winemaking Magarach of the RAS, 31 Kirova Str., 298600 Yalta, Republic of Crimea, Russia

Among the various reasons why wines loose marketable condition, crystalline destabilization due to the loss of tartrate salts is the most frequent one. In most cases, the sediment is represented by potassium, less often - by calcium salt. The change in climatic conditions observed recently, the expansion of the raw material base, introduction of new grapevine cultivation methods and grapes processing technology, as well as the use of modern auxiliary materials for winemaking affect the wine colloidal and mineral composition. This makes the conventional methods of crystalline stabilization less effective, while diagnostic methods to determine wine tendency to crystal formation are insufficient. This literature review presents modern understanding of the mechanisms of potassium bitartrate micro- and macrocrystals formation in wines. It has been demonstrated that crystalline destabilization of wines depends on many diverse factors: wine temperature, the volume fraction of ethyl alcohol, the colloidal substances content, the cation-anion composition determining the $\mathrm{pH}$ value, the ionic strength of the solution and the degree of organic acids dissociation. The quantitative expressions and interrelationships of the potassium cations and tartaric acid anions content destabilizing the wine system are given along with agrotechnical peculiarities of grapevine cultivation and grapes technological processing methods. An argument was made for the new methodological approaches to control and regulate the crystalline stability of wines by studying the qualitative composition of the raw materials and products of their processing at all production stages.

Key words: potassium; tartaric acid; potassium bitartrate; cationanion composition; colloidal substances; agro-technical methods; grape processing methods; crystal formation inhibitors and provocateurs.

ОАним из регламентируемых критериев товарного вида винодельческой продукции явмяется её стабимьность - прозрачность и отсутствие мюбого вида осадка. Среди помутнений вин физико-химического характера наиболее частой явцяется дестабилизация за счет выпадения кристаццов виннокислых солей. В большинстве случаев этот осадок представлен калиевой, реже - кальциевой солью [1-3]. Визуальная схожесть кристалмов с осколками стекца вызывает сомнение потребителя относительно качества и безопасности вина, несмотря на безвреАность Аанных вкцючений Аля зАоровья человека.

Первостепенную роль в обеспечении стабимьности вина играют его физико-химические свойства, которые формируются в цепочке винограА $\rightarrow$ сусло $\rightarrow$ виноматериал $\rightarrow$ вино под Аействием множества факторов: агрокмиматических условий произрастания винограда, технологической схемы его переработки, методов стабилизации. ОАнако изменение кмиматических условий, наблюдаемых за последнее время, расширение сырьевой базы, внедрение новых приемов возделывания винограда и технологии его 
переработки, а также испомьзование современных вспомогательных материалов Аця винодемия вцияет на накопиение в вине веществ, обуслов ивающих Аестабимизацию системы вина, в резумьтате чего общепринятые методы кристамиической стабимизации виноматериалов явцяются недостаточно эффективными. В связи с этим разработка новых методологических подходов ААя контроля и регулирования кристац ической стабимьности вин на основе изучения качественного состава сырья и продуктов его переработки на всех этапах производства явцяется актуацьной и требует более детацьного изучения.

Цемью Аанного митературного обзора явцялось обобщение современных представцений о механизмах и факторах кристацмической кациевой Аестабимизации вин.

Вино преАставцяет собой сложную систему, состав и бацанс компонентов которой обусловцивает ее свойства, в частности, способность образовывать кристациические осаАки малорастворимых сомей винной кислоты. Катионами, участвующими в формировании указанных сомей, явцяются каций и кацьций, в то время как Аругие метам -ионы образуют растворимые соли $и$ бо преАстав ены в вине в незначите ьном количестве, что не позвоцяет активировать процесс кристациобразования.

Органические кислоты в виноградной ягоде в основном преАставцены винной и яблочной, на их Аолю приходится 70-90\% общего содержания кислот [4]. Винная кислота, в отличие от Аругих органических кислот, синтезируется только в ягодах винограАа и в Аругих плодах и фруктах не встречается $[5,6]$.

Винная кислота явцяется Авухосновной (содержит Аве карбоксимьных группы) оксикислотой (соАержит гиАроксимьную группу). Известны три её стереоизомера: мезо-форма (мезовинная кислота) и Aва пространственных энантиомера - D-(-) и L-(+). В винограде винная кислота находится только в виде стереоизомера с правовращающей осью поцяризации L- (+). Аанная кислота мегко отАает протоны, обеспечивая рН водного раствора 3,0-3,5 [7].

Из всех органических кислот, присутствующих в вине, винная явцяется наиболее симьной, о чем свиАете ьствует такой показатемь, как рКа - отрицатемь-

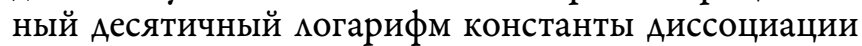
Ка: чем ниже значения показателя, тем более выражены кислотные свойства вещества. Винная кислота в водной среАе имеет Аве константы Аиссоциации $(\mathrm{pKa}):$ по первой ступени - 2,89 и второй - 4,52 [8], по Аругим Аанным - 3,01 и 4,05 соответственно [7]. Аругие органические кислоты вина в порядке возрастания рКа располагаются следующим образом: яблочная $(3,46)$, молочная $(3,81)$, янтарная $(4,18)[7]$.

В винной среде винная кислота образует пять основных вариантов солей: битартрат калия (KHTar),

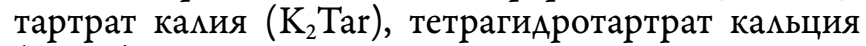
(CaTar), камий-камьций тартрат и тартромацат кацьция $[7,9]$. Соотношение этих тартратных форм в значительной степени опредемяет активную кислотность $(\mathrm{pH})$ : снижение концентрации винной кислоты $\left(\mathrm{H}_{2} \mathrm{Tar}\right)$ приводит к увецичению значений $\mathrm{pH}$ и концентрации битартрата $\left(\mathrm{HTar}^{-}\right)$и тартрата $\left(\operatorname{Tar}^{2-}\right)$.
При рН 2-3,5 винная кислота будет присутствовать в растворенном виде в максимацьном количестве, при pH 3,5-4,5 равновесие савигается в сторону битартрата (максимум его содержания наблюдается вине с $\mathrm{pH} 3,7)$ [9]. В вине 50-70 \% винной кислоты преАставцено в виде НTar-ионов.

Массовая концентрация органических кислот в винограде, а также их соотношение зависит от ряда факторов: сортовая принаАцежность, агрокциматические особенности зоны возАелывания винограда, метеоусловия года и т.А. [1, 7, 10-12]. В незрелой ягоде винограда технических сортов концентрация винной кислоты может Аостигать 15 г/ . По мере созревания ее содержание уменьшается до 2-6 г/ $(0,013-0,04 \mathrm{M})$ в зависимости от сортовых особенностей и терруара (высота наА уровнем моря, сумма активных температур) $[1,7,10-13]$. В южных регионах за счет высоких температур в период созревания накопление винной кислоты составцяет 2-3 г/ , в северных регионах может превышать 6 г/ [7]. В преАелах одной микрозоны на концентрацию винной кислоты в ягоде и вине влияют кАиматические особенности года - отк онение показа-

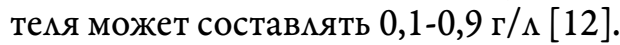

Если в свежем виноградном сусле содержание вин-

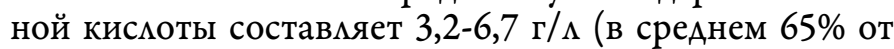
суммы органических кислот), то в готовой продукции (столовые вина) - 1,0-5,7 г/ (в среднем 57\%) [13]. Снижение концентрации винной кислоты в молодых необработанных виноматериацах происходит за счет процессов образования и выпадения в осадок ее нерастворимых солей. Такая кристац ическая самостабимизация приводит к изменению концентрации тартратионов - за Ава месяца отмечается снижение значений с

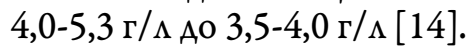

Камий явцяется одним из важнейших макроэлементов, участвующих в метаболизме виноградной ягоды, физиологическая роць которого закцючается в накопцении сахаров, росте кметок, устойчивости к бомезням и абиотическому стрессу за счет стабимизации клеточных мембран, подАержании тургора и участии в транспорте веществ по фиоэме [15]. В соке ягоды этот компонент катионного состава явцяется Аоминирующим [16].

В винах массовая концентрация кация также значительно превацирует наА содержанием остацьных макро- и микроэлементов (кацьция, магния, натрия, жемеза, меАи, цинка и Ар.), и состав яет 65-85\% от суммы катионов [6, 17, 18]. Согмасно китературным данным, его концентрация варьирует в широком Аиапазоне: от 300 до $2500 \mathrm{Mr} / \Lambda(0,005-0,04 \mathrm{M})[17,19]$.

Содержание камия в вине зависит от особенностей химического состава почвы виноградников: при концентрации 7,5 мг/кг в почве его содержание в вине со-

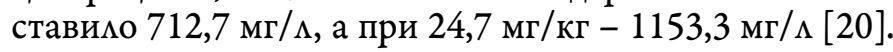
Катионный состав ягоды винограда связан с площадью питания виноградного растения, которую возможно регулировать агротехническими приемами. Более высокое содержание камия характерно Аля виноматериалов, полученных из винограАа, выращенного по схеме посаАки $3,5 \times 1,5$ и $3,5 \times 2$ (в среАнем 541 мг/ 1 ), по сравнению со схемой $2,5 \times 1,2,5 \times 1,5$ и $3 \times 2$ (в среАнем $476 \mathrm{мг} / \Lambda$ ) [21]. Концентрация калия в вине опредемя- 


\section{ВИНОДЕЛИЕ}

Аестабимизация вин.

Кристам ообразование камиевых сомей

ется сортовыми свойствами винограда $[16,18]$, что связано с метаболическими особенностями растения. В красных виноматериалах, выработанных из винограАа разных сортов по иАентичной технологии и в пределах одного преАприятия, разница в содержании

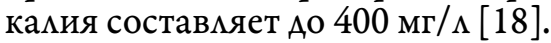

Способ переработки винограда оказывает существенное вмияние на содержание кация в вине. Брожение мезги обеспечивает бомее высокую концентрацию камия в виноматериаме по сравнению с брожением сусла, что связано с экстрагированием катионов из тверАых частей грозАи (кожица и мякоть ягоды, семена, гребни) $[6,18,22,23]$. Установлено, что Аця бемых вин этот показатемь составцяет $850 \pm 80 \mathrm{Mг} / \Lambda$, розовых $-900 \pm 200 \mathrm{мг} / \Lambda$, красных $-1100 \pm 200 \mathrm{мг} / \Lambda$ [24]. Разница по содержанию калия межАу белыми и красными виноматериалами одного года урожая и оАной зоны воздемывания достигает 365 мг/ [18].

Регионы воздемывания винограда обусловцивают разцичное содержания калия в винопродукции: в стомовых виноматериалах, выработанных в Германии, соАержание камия составимо 594-1139 мг/ [19], ОАесской

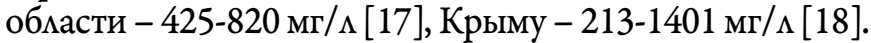

Массовая концентрация кация и винной кислоты - основных участников кристамлической Аестабимизации вин, по Аанным разАичных авторов, варьирует в широких пределах. Помимо перечисленных факторов, это связано с тем, что готовая продукция, в отличие от необработанных виноматериалов, подвержена разАичным технологическим воздействиям, направленным на удацение указанных компонентов Аця обеспечения кристаццической стабимьности вина. Снижение содержания винной кислоты и камия может быть Аостигнуто разАичными методами: обработкой виноматериалов холодом, применением катионнообменных смол ими эмектродиализа $[1,7,25,26]$. Эффективному снижению концентрации кация в вине также может способствовать обработка природными цеолитами [27].

ОАнако в научной $и$ иературе неАостаточно преАставлена роль изменения агрокмиматических условий выращивания винограда в накопмении винной кислоты и калия, а также не установцено их соотношение и оптимацьное содержание, обеспечивающее устойчивость вина к кристамлообразованию.

Считается, что ионы камия образуют нерастворимые соединения только с винной кислотой, но инертны по отношению к биополимерам вина, не вмияя на его комиоиАную стабицьность [1]. ОАнако посиеАними исследованиями было показано, что ионы камия и кацьция способны селективно связываться с некоторыми формами фенольных веществ, в частности с трии тетрамерами цикмических процианидинов [28].

Химический процесс формирования битартрата кация (KНTar) вкцючает Аиссоциацию винной кислоты (Tar) по Авум ступеням и образование нерастворимого соеАинения:

$$
\begin{aligned}
\mathrm{H}_{2} \mathrm{Tar} & \rightleftharpoons \mathrm{H}^{+}+\text {HTar }^{-} \\
\mathrm{HTar}^{-} & \rightleftharpoons \mathrm{H}^{+}+\text {Tar }^{2-} \\
\mathrm{K}^{+}+\mathrm{HTar}^{-} & \rightleftharpoons \text { KHTar } \downarrow
\end{aligned}
$$

Аанные реакции явцяются обратимыми, и при
Гнииомедова Н.В., Аникина Н.С.,

$$
\text { Червяк С.H. }
$$

изменении физических условий ими концентрации Аругих компонентов в системе наблюдается соответствующий сАвиг химического равновесия. Согмасно закону Аействия масс, чем выше концентрация участников химического процесса или оАного из них, тем выше скорость реакции [29] и тем активнее происходит образование нерастворимых соединений и выпадение осадка. Это касается как чистых растворов [29], так и вин [14], которые можно рассматривать как растворы, пересыщенные битартратом кация. Теоретически 1 г винной кислоты может взаимодействовать с 0,26 г калия с образованием 1,26 г битартрата кация [30], который обладает растворимостью в воАном растворе 5,4 г/ $\Lambda$ (при $\left.20^{\circ} \mathrm{C}\right)$ [8].

Процесс образования визуацьно заметного осаАка KHTar вкмючает в себя три стадии: перенасыщение системы активными ионами; образование центров кристациизации (зародышевых кристацлов); рост

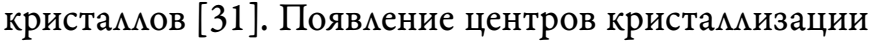
в чистых растворах может происходить спонтанно непосредственно во всем объеме («гомогенное зароАышеобразование»). В винах этот процесс протекает вАоль поверхностей («гетерогенное зародышеобразование»), что минимизирует площаАь граней кристацца и уменьшает вероятность повторного растворения. Это обусловцивает начацо роста кристацлов битартрата кация на дефектах поверхности стенок емкостей (резервуары, бочки) ими на разцичных вкмючениях, например, Арожжевых кметках $[1,31]$.

Образование зародышевых центров Аця системы энергетически невыгодно: частицы, располагающиеся на границе раздела фаз, имеют менее прочные свя-

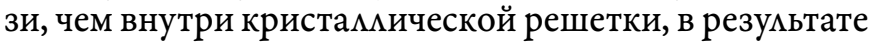
чего скорость растворения кристацмов может превышать скорость их роста. Некоторое количество центров кристациизации может преодолеть критический раАиус яАра, то есть снизить отношение поверхности к объему, что приводит к уменьшению свободной энергии поверхности и формированию кристамма. Обеспечивая образование ядер с меньшим Аиаметром путем снижения межфазной энергии, можно управцять Аанным процессом. Как правимо, охлаждение вина Ао $0{ }^{\circ} \mathrm{C}$ приводит к снижению растворимости КHTar в 2-3 раза, что обусловливает активное образование ялер кристамлов с Аамьнейшим их развитием [31].

При обработке виноматериала холодом существенное вцияние на скорость кристацообразования, размер сформировавшихся частиц, качество обработки, и, соответственно, гарантийный срок хранения винопродукции оказывают режимы и параметры процесса. Ускорить выпадение виннокислых кристациов позвомяет введение «затравки» [32], размер частиц которой опредемяет характер образовавшегося осаАка [33]. Мелкодисперсные кристациы (0,25-0,5 мм) экзогенного битартрата кация образуют множество центров кристаммизации и формируют хлопьевидные вкцючения, махая масса которых замеАцяет седиментацию; частицы более 1 мм, напротив, Аостаточно тяжелы и быстро опускаются, не успевая Аостраивать кристациическую решетку ионами калия и винной кислоты, растворенными в вине. Показано, что опти-

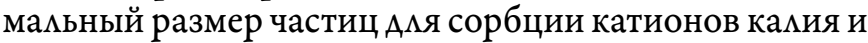


анионов винной кислоты составцяет 0,5-0,75 мм [33].

Резкое понижение температуры при обработке виноматериалов холодом приводит к быстрому зароАышеобразованию и формированию множества мекких пцастинчатых кристалмов, скмонных к быстрому растворению. Кристамлы бомее крупного размера образуются при медленном охлаждении виноматериала, что обеспечивает его эффективную фильтрацию после обработки [34].

Кристамлическая дестабимизация обусловмена не только балансом «винная кислота - каций» в системе вина, но и определяется целым рядом химических факторов (спиртуозность, катионно-анионный состав, содержание высокомолекулярных веществ), провоцирующих мибо ингибирующих кристамлообразование [35-38].

Битартрат кация не Аиссоциирует в этицовом спирте, поэтому в модельных растворах, имитирующих вино, растворимость KHTar в 2-3 раза ниже, чем в воде [1]. Повышение спиртуозности с $10 \%$ об. до $14 \%$ об. приводит к увеличению температуры насыщения с $15^{\circ} \mathrm{C}$ до $20,3^{\circ} \mathrm{C}$ [37], чем выше значения которой, тем насыщеннее система KHTar, и тем выше риск запуска кристамєообразования при охлаждении вина. В производственных условиях влияние этанола на потерю растворимости битартратом калия можно наблюдать в процессе брожения сусла - повышение содержания этилового спирта в результате метаболизма Арожжевых кцеток приводит к быстрому накопиению кристалмического осадка на Ане емкости [37].

Важным моментом, вАияющим на образование кристаццов КHTar, явцяется концентрация ионов, не участвующих в кристацлообразовании, но увеличивающих ионную силу раствора. Это так называемый «сомевой эффект», который повышает растворимость осадков в присутствии сильных эмектролитов. ВАияние постороннего электролита на растворимость объясняется эмектростатическим взаимодействием межАу ионами-участниками процесса и посторонними ионами, что вызывает сАвиг равновесия реакции осажАения-растворения. Как правимо, чем больше концентрация электролита, тем сильнее это вАияние [39]. Этим можно объяснить ингибирующий эффект катионов натрия и магния на скмонность вин к кристалмической дестабилизации с участием битартрата калия [38].

Моносахариды (глюкоза и фруктоза), присутствующие в вине в остаточном количестве, не оказывают существенного влияния на процесс кристацмообразования. ОАнако высокое содержание сахаров привоАит к ингибированию седиментации образовавшихся кристаццов, что обусловцено более высокой вязкостью среды. Это подтвержАается результатами холоАовой обработки белых столовых виноматериалов (при температуре минус $5^{\circ} \mathrm{C}$ ) - процесс кристамлообразования в сухих образцах Алимся 6-7 сут., в полуслаАких - 10 сут. [19].

Формированию и выпадению кристацмов препятствует наличие в среде собственных высокомолекумярных веществ, к которым относятся полисахариды винограда [36], фенольные вещества [22, 36, 37], а также маннопротеины дрожжевых кметок, которые высвобожАаются во время брожения и в процессе их автолиза [40]. Содержание таких веществ в белых и красных винах существенно разцичается, что влияет на скорость выпадения осадка КНTar, о чем свидетельствует изменение концентрации калия в виноматериалах до и после холодовой обработки. Так, в бе$\Lambda$ ых и красных образцах снижение содержания калия составцяет $58 \%$ и $13 \%$ соответственно [22], несмотря на то, что красные вина характеризуются более высокой концентрацией катионов.

Считается, что механизмы соосаждения высокомолекулярных веществ на поверхности кристацлов разцичны [37]. Фенольные вещества не могут прочно взаимодействовать с битартратом калия и сорбируются посреАством Н-связей, ослабленных отрицательным зарядом тартрат-иона, при этом, окрашивая кри-

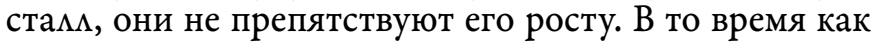
белковые молекулы взаимодействуют с поверхностью за счет электростатических сил, что приводит к нарушению процесса построения кристалиической решетки и изменению морфологии кристамла [37].

Защитный эффект некоторых высокомолекулярных веществ положен в основу технологических метоАов борьбы с появлением кристаццического осадка в вине. Внесение препаратов на основе карбоксиметилцеммюлозы [41-43], полиаспартата [44], метавинной кислоты [42, 45], искусственно выдеменных маннопротеинов $[42,46]$ продмевают срок кристалмической стабильности и служат Аополнительной гарантией качества вина. ОАнако данные вещества проявцяют Аолжный защитный эффект только при незначительной исходной скмонности вин к кристаццообразованию, внесение их целесообразно после предварительной обработки виноматериалов с выведением из растворенного состояния битартрата калия. Следует также отметить, что добавка некоторых защитных коммоидов может провоцировать коммоидную нестабимьность готовой продукции.

Таким образом, Аестабилизация определяется соАержанием и балансом основных участников кристацмообразования, наличием в системе вина провокаторов и ингибиторов этого процесса, а также температурными условиями.

Отсутствие Аостаточных знаний о вАиянии новых вспомогательных материалов, агротехнических и технологических приемов на кристалмическую стабимьность вин обусмовливает необходимость разработки новых методологических подХодОВ Аця контроля и регулирования кристаццической стабицьности вин на основе изучения качественного состава сырья и проАуктов его переработки на всех этапах производства.

\section{Источник финансирования}

Работа выполняется в рамках Государственного задания Минобрнауки России № 0833-2019-0024.

\section{Financing source}

The study was conducted under public assignment № 0833-2019-0024.

\section{Конфликт интересов}

Не заявлен.

\section{Conflict of interests}

No declared.

\section{Список литературы/ References}

1. Waterhouse A.L., Sacks G.L., Jeffery D.W. Understanding 
wine chemistry. Chichester, West Sussex: John Wiley \& Sons, Inc. $2016.443 \mathrm{p}$.

2. Lasanta C., Gómez J. Tartrate stabilization of wines. Trends in Food Science and Technology. 2012. 28 (1). pp. 52-59.

3. Храпов А.А., Агеева Н.М. Мониторинг кристаллических помутнений винодельческой продукции, производимой предприятиями Краснодарского края // Известия ВУЗов. Пищевая технология. 2016. № 4. С. 119-122.

[Khrapov A.A., Ageeva N.M. Monitoring of crystalline turbidity wine products manufactured by enterprises of Krasnodar region. Izvestiya vuzov. Pishchevaya tekhnologiya. 2016. № 4 . pp. 119-122 (in Russian)].

4. Cosme F., Vilela A., Jordão A.M. The role of tartaric acid in grapes and wines (Book Chapter), 2017. Advances in Chemistry Research 40. pp. 198-216.

5. Шобингер У. Фруктовые и овощные соки: научные основы технологии / Пер. с нем. Под общ. науч. ред. А.Ю. Колеснова, Н.Ф. Берестеня и А.В. Орещенко. СПб: Профессия, 2004. 640 с.

[Schobinger U. Fruktovye i ovoshhnye soki: nauchnye osnovy tehnologii [Fruit and vegetable juices: scientific basis of technology] / Per. s nem. Pod obshh. nauch. red. A.Ju. Kolesnova, N.F. Berestenja i A.V. Oreshhenko. SPb: Professija. 2004. 640 p. (in Russian)].

6. Аникина Н.С., Жилякова Т.А., Гержикова В.Г., Владимирова Л.Г., Семенчук А.В., Черкашина А.Ф., Сарварова Н.Н., Горбунова Е.В. Минеральный состав виноградных вин - идентификационный признак их аутентичности // «Магарач». Виноградарство и виноделие, 2010. № 1. С. 33-35.

[Anikina N.S., Zhiljakova T.A., Gerzhikova V.G., Vladimirova L.G., Semenchuk A.V., Cherkashina A.F., Sarvarova N.N., Gorbunova E.V. The mineral composition of grape wines is an identification sign of their authenticity. Magarach. Vinogradarstvo i vinodelie=Magarach.Viticulture and Winemaking. 2010. № 1. pp. 33-35 (in Russian)].

7. Ribereau-Gayon P., Yves G., Maujean A., D. Dubourdieu Handbook of Enology, vol. 2, John Wilei \& Sons, England. 2006. pp. 369-386.

8. Лурье Ю.Ю. Справочник по аналитической химии. М.: Химия. 1979. С. 322.

[Lure Yu.Yu. Spravochnik po analiticheskoy himii [Handbook of Analytical Chemistry]. Moscow: Himiya. 1979. pp. 322 (in Russian)].

9. Sirromet Wines Pty (Ltd). Wine pH \& Acidity. Concepts and chemistry of $\mathrm{pH}$, organic acids, buffer capacity and wine quality implications of $\mathrm{pH}$. URL: http://slideplayer.com/ slide/8339529/ (дата обращения: 22.04.2019)

10. Даудова Т.И., Власова О.К. Состав и содержание органических кислот в соке и виноматериалах из винограда, выращенного в северо-западной зоне Дагестана // Известия высших учебных заведений. Пищевая технология. 2018. № 1 (361). С. 28-31.

[Daudova T.I., Vlasova O.K. Composition and content of organic acids in juice and wine from grapes grown in the north-western zone of Dagestan. Izvestija vysshih uchebnyh zavedenij. Pishhevaja tehnologija. 2018. № 1 (361). pp. 28-31 (in Russian).

11. Остроухова Е.В., Пескова И.В., Погорелов Д.Ю. Профиль органических кислот винограда белых сортов, произрастающих в Крыму // Плодоводство и виноградарство Юга России. 2019. № 56 (02). С. 122-132.

Ostroukhova E., Peskova I., Pogorelov D. The organic acid profile of white grapes varieties growing in Crimea. Plodovodstvo i vinogradarstvo Juga Rossii. 2019. № 56 (02). pp. 122-132 (in Russian)].

12. Макаров А.С., Яланецкий А.Я., Лутков И.П., Шмигельская Н.А., Шалимова Т.Р., Максимовская В.А., Кречетова В.В., Погорелов Д.Ю., Грамотенко А.П. Особенности состава органических кислот в виноматериалах южного берега Крыма // «Магарач». Виноградарство и виноделие.
2018. № 1. C. 36-39.

[Makarov A., Yalanetskii A., Lutkov I., Shmigelskaia N., Shalimova T., Maksimovskaia V., Krechetova V., Pogorelov D., Gramotenko A. Peculiarities of the composition of organic acids in wine materials of the southern coast of Crimea. Magarach. Vinogradarstvo $i$ vinodelie=Magarach. Viticulture and Winemaking. 2018. № 1. pp. 36-39 (in Russian)].

13. Гниломедова Н.В., Аникина Н.С., Гержикова В.Г., Погорелов Д.Ю., Рябинина О.В., Ермихина М.В. Профиль органических кислот как критерий идентификации продуктов виноградного происхождения // Пиво и напитки. 2016. № 5. С. 40-43.

[Gnilomedova N., Anikina N., Gerzhikova V., Pogorelov D., Ryabinina O., Ermikhina M. Profile of Organic Acids as a Criterion for Identifying the Origin of Wine Products. Pivo i napitki. 2016. № 5. pp. 40-43 (in Russian)].

14. Lampír, L., Žaloudek, J. Influence of summer management practices and date of harvesting on organic acids concentration and sugar concentration in grapes of Vitis vinifera L., cv. Riesling. Horticultural Science. 2018. 45(4). pp. 213-218.

15. Rogiers S.Y., Coetzee Z.A., Walker R.R., Deloire A., Tyerman S.D. Potassium in the grape (Vitis vinifera L.) berry: Transport and function. Frontiers in Plant Science. 2017. Vol. 8. 2017. pp. 1629.

16. Андреева В.Е., Калмыкова Н.Н., Калмыкова Е.Н., Гапонова Т.В. Сравнительный анализ содержания катионов щелочных металлов сусел и молодых вин, полученных из белых сортов винограда межвидового происхождения // «Магарач». Виноградарство и виноделие. 2018. № 3 (105). C. 67-68.

[Andreyeva V.Y., Kalmykova N.N., Kalmykova E.N., Gaponova T.V. Comparative analysis of cation content of alkali metals in must and young wines produced from white grape varieties of inter-specific origin. Magarach. Vinogradarstvo $i$ vinodelie $=$ Magarach. Viticulture and Winemaking. 2018. № 3 (105). pp. 67-68 (in Russian)].

17. Ткаченко О.Б., Иукуридзе В.Г. Особенности состава минерального комплекса белых столовых виноматериалов агроклиматической зоны Шабо // Пищевая наука и технология. 2014. Т. 29. № 4. С. 55-59.

[Tkachenko O.B., Iukuridze V.G. Features of the mineral complex of white table wine materials of the agro-climatic zone of Shabo. Pishhevaja nauka i tehnologija. 2014. Vol. 29. №. 4. pp. 55-59 (in Russian)].

18. Макаров А.С., Лутков И.П., Шалимова Т.Р., Бурдинская А.В., Жилякова Т.А., Аристова Н.И. Исследование катионного состава виноматериалов для игристых вин, выработанных в различных хозяйствах Крыма // Плодоводство и виноградарство Юга России. 2016. № 39 (3). С. 56-67.

[Makarov A., Lutkov I., Shalimova T., Burdinskaia A., Zhilyakova T., Aristova N. Study of cation composition of wine materials for sparkling wines, produced in the various farms of the Crimea. Plodovodstvo i vinogradarstvo Juga Rossii. 2016. № 39 (3). pp. 56-67 (in Russian)].

19. Храпов А.А., Агеева Н.М., Мошель Д. Влияние вязкости вина на кристаллообразование при внесении битартрата калия // Известия высших учебных заведений. Пищевая технология, 2017. № 2-3 (356-357). С. 28-30.

[Khrapov A.A., Ageeva N.M., Moschell D. Effect of viscosity of the wine on the crystal formation at addition the bitartrate potassium. Izvestija vysshih uchebnyh zavedenij. Pishhevaja tehnologija. 2017. № 2-3 (356-357). pp. 28-30 (in Russian)].

20. Кузьменко А.С., Кузьменко Е.И., Ткаченко Д.П. Мониторинг содержания калия, кальция, натрия, магния в системе почва-виноград-вино, в контексте формирования типичных вин Северного Причерноморья // Научные труды ГНУСКЗНИИСиВ, 2013. Т. 4. С. 47-53.

[Kuz'menko A., Kuz'menko E., Tkachenko D. Monitoring of potassium, calcium, sodium, magnesium in the soil-grape-wine in the context of the formation of typical wines of the northern Black Sea. Nauchnye trudy GNUSKZNIISiV. 2013. Vol. 4. 
pp. 47-53 (in Russian)].

21. Ширшова А.А., Павлюкова Т.П., Прах А.В., Гугучкина Т.И. Катионный состав белых столовых виноматериалов из сорта Рислинг в зависимости от схемы посадки винограда // Плодоводство и виноградарство Юга России. 2016. № 39 (3). С. 50-55.

[Shirshova A., Pavluykova T., Prakh A., Guguchkina T. Cation composition of Riesling white table wine depending on use of agric and technical methods. Plodovodstvo i vinogradarstvo Juga Rossii. 2016. № 39 (3). pp. 50-55 (in Russian)].

22. Walker R., Blackmore D. Potassium concentration and $\mathrm{pH}$ inter-relationships in grape juice and wine of Chardonnay and Shiraz from a range of rootstocks in different environments. Australian Journal of Grape and Wine Research, 2012. Vol. 18, Issue 2. pp. 183-193. DOI: 10.1111/j.1755-0238.2012.00189.x

23 Zamfir C.I., Cotea V.V., Luchian C.E., Niculaua M., Odägeriu G. The influence of different prefermentative maceration processes and tartaric stabilization treatments on the color, cation content and other physico-chemical parameters of 'Băbească neagră' rosé wines // Vitis - Journal of Grapevine, 2014. Research 53(1), pp. 45-52.

24. Шелудько О.Н., Стрижов Н.К. Применение комплексного анализа при оценке качества винодельческой продукции //Известия высших учебных заведений. Пищевая технология. 2018. № 5-6 (365-366). С. 116-120.

[Sheludko O.N., Strizhov N.K. Application of integrated analysis in the evaluation of the quality of wine products. Izvestija vysshih uchebnyh zavedenij. Pishhevaja tehnologija. 2018. № 5-6 (365-366). pp. 116-120 (in Russian)].

25. Corti S.V., Paladino, S.C. Tartaric stabilization of wines: Comparison between electrodyalisis and cold by contact. Revista de la Facultad de Ciencias Agrarias, 201648(1). pp. 225-238.

26. Ibeas V., Correia A.C., Jordão A.M. Wine tartrate stabilization by different levels of cation exchange resin treatments: Impact on chemical composition, phenolic profile and organoleptic properties of red wines. Food Research International, 2015. 69. pp. 364-372.

27. Mercurio M., Bish D.L., Cappelletti P., De Gennaro B., De Gennaro M., Grifa C., Izzo F., Mercurio V., Morra V., Langella A. The combined use of steam-treated bentonites and natural zeolites in the oenological refining process. Mineralogical Magazine, 2016. 80(2). pp. 347-362.

28. Longo E., Rossetti F., Merkyte V., Obiedzińska, A., Boselli E. Selective binding of potassium and calcium ions to novel cyclic proanthocyanidins in wine by HPLC-HRMS. Rapid Communications in Mass Spectrometry, 2018. 32(18). pp. 1637-1642 Reads. DOI: 10.1002/rcm.8221.

29. Коровин Н.В., Масленникова Г.Н., Мингулина Э.И., Филиппов Э.Л. Курс общей химии. М.: Высшая школа, 1990. С. $109-110,140-141$.

[Korovin N.V., Maslennikova G.N., Mingulina E.I., Filippov E.L. Kurs obschey himii [General chemistry course]. Moscow: Vyisshaya shkola, 1990. pp. 109-110, 140-141 (in Russian)].

30. Zoecklein B. A Review of Potassium Bitartrate Stabilization of Wines. Department of Horticulture. Virginia Polytechnic Institute and State University, 1988. URL: https://www.apps. fst.vt.edu/extension/enology/downloads/PotBitar.pdf (дата обращения: 22.04.2019).

31. De Yoreo J.J., Vekilov P.G. Principles of crystal nucleation and growth. Reviews in Mineralogy and Geochemistry, 2003. Vol. 54 (1). pp. 57-93.

32. Sturza R., Covaci E Tartaric stabilization of young wines and thermodynamic indices of stability. Rev. Roum. Chim., 2015, 60(11-12), pp. 1019-1024.

33. Храпов А.А., Агеева Н.М. Влияние степени дисперсности препаратов битартрата калия на эффективность их использования для стабилизации вин // Известия высших учебных заведений. Пищевая технология, 2016. № 5-6 (353-354). C. 38-41.
[Khrapov A.A., Ageeva N.M. Impact of the degree of dispersion of potassium bitartrate preparations on efficiency of their use for stabilization of wines. Izvestija vysshih uchebnyh zavedenij. Pishhevaja tehnologija. 2016. № 5-6 (353-354). pp. 38-41 (in Russian)].

34. Риберо-Гайон Ж., Пейно Э., Риберо-Гайон П., Сюдро П. Теория и практика виноделия / Под ред. Г. Г. Валуйко. М.: Легкая и пищевая пром-сть, 1981. Т. 4. 415 с.

[Ribereau-Gayon J., Peynaud E., Ribereau-Gayon P., Sudraud P. Teoriya i praktika vinodeliya. T. 2-4 [Theory and practice of winemaking]. Moscow: Legkaya i pishchevaya promyshlennost'. 1981. Vol. 4. 415 p. (in Russian)].

35. Gerbaud V., Gabas N., Blouin J., Laguerie C. Nucleation studies potassium hydrogen tartrate in model solutions and wines. Journal of Cristal Growth. 1996. 199. pp. 172-178.

36.Gerbaud V., Gabas N., Jacques Blouin, Pellerin P., Moutounet $\mathrm{M}$. Influence of wine polysaccharides and polyphenols on the crystallization of potassium hydrogen tartrate. Journal international des ciences de la vigne et du vin, 1997. Vol. 31. № 2. pp. 65-83.

37. Lambri M., Colangelo D., Dordoni R., De Faveri D.M. The effects of different protein:tannin ratios on the tartrate-holding capacity of wine model solutions. Food research international. 2014. Vol. 62. pp. 441-447.

38. Гержикова В.Г., Червяк С.Н., Погорелов Д.Ю., Михеева Л.А., Щербина В.А. Влияние катионов на прогнозирование стабильности белых столовых виноматериалов к кристаллическим помутнениям // «Магарач». Виноградарство и виноделие. 2016. № 3. С. 25-27.

[Gerzhikova V., Cherviak S., Pogorelov D., Mikheieva L., Shcherbina V. The Influence of Cations on the Prediction of White Table Base Wine Stability to Crystal Haze. Magarach. Vinogradarstvo $i$ vinodelie $=$ Magarach. Viticulture and Winemaking. 2016. № 3. pp. 25-27 (in Russian)].

39. Крешков А.П. Основы аналитической химии. Теоретические основы. Количественный анализ. М.: Химия, 1971. $456 \mathrm{c.}$

[Kreshkov A.P. Osnovy analiticheskoj himii. Teoreticheskie osnovy. Kolichestvennyj analiz [Fundamentals of Analytical Chemistry. Theoretical basis. Quantitative analysis]. Moscow: Himija. 1971.456 p. (in Russian)].

40. Ortega-Heras M., González-SanJosé M.L. Mannoproteins and enology: Tartrate and protein stabilization. Recent advances in wine stabilization and conservation technologies, 2016. pp. 95-109.

41. Bajul A., Gerbaud V., Teychene S., Devatine A., Bajul G. Effect of carboxymethylcellulose on potassium bitartrate crystallization on model solution and white wine. Journal of Crystal Growth. 2017. Vol. 472. pp. 54-63. doi.org/10.1016/j. jcrysgro.2017.03.024

42. Stabilisation des vins. Stabilisation tartrique, protéique, colloïdale et microbiologique. URL: https://laffort.com/ gammes/stabilisation/ (дата обращения: 16.04.2019).

43. Claus H., Tenzer S., Sobe M., Schlander M., König H., Fröhlich J. Effect of carboxymethyl cellulose on tartrate salt, protein and colour stability of red wine. Australian Journal of Grape and Wine Research, 2014. 20. pp.186-193.

44. Bosso A., Panero L., Petrozziello M., Sollazzo M., Asproudi A., Motta S., Guaita M. Use of polyaspartate as inhibitor of tartaric precipitations in wines. Food Chemistry, 2015. 185. 17346. pp. 1-6.

45. Metatartaric acid: physicochemical characterization and analytical detection in wines and grape juices / Sprenger, S., Hirn, S., Dietrich, H., Will, F. European Food Research and Technology, 2015. 241(6). pp. 785-791.

46. Lankhorst P.P., Voogt B., Tuinier R., Lefol B. Pellerin P., Virone C. Prevention of Tartrate Crystallization in Wine by Hydrocolloids: The Mechanism Studied by Dynamic Light Scattering. Journal of Agricultural and Food Chemistry, 2017. Vol. 65, Issue 40. pp. 8923-8929. 